\title{
Tooth ankylosis in deciduous teeth of children with cleft lip and/or palate
}

\section{Anquilose dentária na dentição decídua em crianças com fissura de lábio e/ou palato}

\author{
Andreza Maria Fábio Aranha* \\ Cristiane Duque* \\ Juliana Yassue Barbosa da Silva* \\ Cleide Felício de Carvalho Carrara** \\ Beatriz Costa** \\ Marcia Ribeiro Gomide**
}

\begin{abstract}
The present study aimed at evaluating the prevalence of tooth ankylosis in deciduous molars of Caucasian children with cleft lip and/or palate aged 5 to 12 years, of both genders. A total of 330 patients seen at the Hospital for Rehabilitation of Craniofacial Anomalies of the University of São Paulo for routine treatment were clinically evaluated. The prevalence of ankylosis was analyzed in relation to gender, age range (5-7, 8-10, 11-12 years), type of cleft, affected tooth and arch. The total group showed a prevalence of $18 \%$, with no statistical difference between genders and among types of cleft; ankylosis was more often in the mandibular arch, lower first molars and among children in the age ranges 8-10 and 11-12 years. The results agreed with those observed in the related literature for patients without clefts, pointing out the absence of influence of the cleft on the prevalence of ankylosis. This reinforces the importance of early diagnosis of this anomaly and of the treatment of choice, which are similar in patients with or without clefts.
\end{abstract}

DESCRIPTORS: Tooth, deciduous; Ankylosis.

RESUMO: Este estudo avaliou a prevalência de anquilose dentária em molares decíduos de portadores de fissura de lábio e/ou palato, brancos, de ambos os sexos, com idade entre 5 e 12 anos. Um total de 330 pacientes atendidos no Hospital de Reabilitação de Anomalias Craniofaciais da Universidade de São Paulo para tratamento de rotina foi clinicamente avaliado. A prevalência de anquilose foi analisada em relação a gênero, idade (5-7; 8-10; 11-12 anos), tipo de fissura, dente e arco afetados. O grupo total demonstrou prevalência de $18 \%$, sem diferença estatística entre gêneros e tipos de fissura, sendo mais acometido o arco mandibular, o primeiro molar inferior e as faixas etárias de 8 a 10 e de 11 a 12 anos. Os resultados estão de acordo com aqueles observados na literatura para pacientes sem fissuras, destacando a ausência da influência das fissuras na prevalência de anquilose. Isso reforça a importância do diagnóstico precoce dessa anomalia e do tratamento de escolha, que são similares aos de pacientes sem fissuras.

DESCRITORES: Dente decíduo; Anquilose.

\section{INTRODUCTION}

Tooth ankylosis is defined as an anatomical fusion between the cement and/or dentin and the alveolar bone ${ }^{13}$, which is likely to occur anytime during tooth eruption, or even after establishment of the occlusal contact ${ }^{15}$. The earlier the ankylosis process, the more severe its prognosis will be, even causing the preclusion of normal tooth exfoliation, leading to a delay of as much as 6 months in the eruption of the successor permanent tooth ${ }^{8,9}$. Therefore, the early diagnosis of ankylosis by den- tists is important, due to its unpredicted potential for the development of malocclusions ${ }^{16}$.

The etiology of ankylosis is still unknown, but local metabolism disturbances, excessive masticatory loads and genetic disturbances may be related to its development ${ }^{3}$. The possibility of a hereditary feature is currently under discussion ${ }^{12,13}$, since the genetically determined defect of the periodontal membrane might explain the ankylosis of impacted teeth $^{3}$.

\footnotetext{
*Graduate Students; **Pediatric Dentists of the Hospital for Rehabilitation of Craniofacial Anomalies - School of Dentistry of Bauru, University of São Paulo.
} 
Aranha AMF, Duque C, Silva JYB, Carrara CFC, Costa B, Gomide MR. Tooth ankylosis in deciduous teeth of children with cleft lip and/or palate. Braz Oral Res 2004;18(4):329-32.

Clinically, ankylosed teeth present infraocclusion, since they remain static whereas adjacent teeth move vertically because of the growth and development of the alveolar process. This leads them to occupy a more inferior position in relation to the occlusal plane ${ }^{14,15}$. Upon percussion, a clear (bass) sound is noticed, whereas the intact periodontal membrane, which absorbs part of the impact, deadens the sound yielded by a normal tooth. Ankylosed teeth do not present mobility, even in the most advanced cases of root resorption.

The radiographic diagnosis may sometimes be accomplished through observation of a discontinuity in the periodontal space ${ }^{15}$. Nevertheless, the radiographic interpretation depends on the localization of the ankylosis; and its detection on the palatal and buccal aspects is impossible, due to the superposition of structures ${ }^{2}$.

The treatment of ankylosis depends on the involved tooth, degree of infraocclusion, age and patient compliance $e^{1,5,8,10}$, and on the developmental degree of the successor tooth ${ }^{16}$. It includes prosthetic rehabilitation and an attempt to luxate or extract the involved tooth ${ }^{1}$. A more conservative approach is chosen in cases of infraocclusion of deciduous molars without disturbance to the normal development of occlusion, comprising just regular clinical and radiographic follow-ups at 6-month intervals. In the most severe cases, extraction of the involved deciduous molars is required, followed by strict space maintenance or even its mechanic recovery ${ }^{17}$.

The frequency of tooth ankylosis presents large variations among studies, varying from $1.08 \%{ }^{11}$ up to $24.8 \%{ }^{12}$.

Regarding gender, there is no agreement in the related literature. Predominance among females has been reported ${ }^{15,14}$, but Koyoumdjisky-Kaye, Steigman ${ }^{12}$ (1982) found this tendency just for the age range between 5 and 7 years, whereas other authors demonstrated higher frequency among males $^{10}$, and even no differences at all ${ }^{6,12}$.

In relation to age, some authors ${ }^{6,12,18}$ mentioned a tendency towards an increase in the number of cases of ankylosis upon aging.

Regarding tooth and arch, most of the studies report that the first molars and the mandibular dental arch are most frequently affected ${ }^{6,7,10,12,18}$.

The aim of this study was to characterize the prevalence of ankylosis in deciduous molars of individuals with cleft lip and/or palate due to the importance of early diagnosis of this anomaly to prevent the development of malocclusions, since these patients already present changes in anatomy and tooth position, which are inherent to their malformation.

\section{MATERIAL AND METHODS}

For accomplishment of this study, a total of 330 individuals with cleft lip and/or palate were evaluated, aged 5 to 12 years, Caucasian, of both genders and without any other type of anomaly. The subjects were seen at the Hospital for Rehabilitation of Craniofacial Anomalies, University of São Paulo (HRAC-USP), Bauru, Brazil, for routine treatment.

The Ethics Committee of the HRAC-USP previously approved the study design and the children's caretakers signed a Consent Term for participation in the study after receiving previous information about it.

Standardized forms were employed to record the identification data of the individuals, such as: full name, gender, birth date, dental status, type of cleft, presence of infraocclusion and, when present, the tooth and dental arch affected.

All individuals were examined in a dental chair in the Pediatric Dentistry Sector of the HRAC-USP, with a dental mirror and under artificial light. A previously calibrated single examiner separately analyzed each dental arch according to the concomitant presence of the following:

- infraocclusion: when the occlusal surface of the tooth was at least $1 \mathrm{~mm}$ below the occlusal plane of the adjacent teeth ${ }^{4}$;

- interarch relationship: absence of occlusal contact with the antagonist tooth;

- absence of mobility.

As an auxiliary method, percussion of the tooth was employed, with observation of a bass sound, even though this feature is not always present in ankylosed teeth.

Radiographies were not employed for evaluation of ankylosis, since obliteration of the periodontal ligament is not always observed on these teeth. Deciduous molars with extensive carious lesions or large restorations were excluded.

Data were submitted to $\chi^{2}$, at a significance level of $5 \%$.

\section{RESULTS}

A total of 330 individuals were analyzed, among which 71 presented cleft lip, 194 presented cleft lip and palate and 65 presented cleft palate. 
Aranha AMF, Duque C, Silva JYB, Carrara CFC, Costa B, Gomide MR. Tooth ankylosis in deciduous teeth of children with cleft lip and/or palate. Braz Oral Res 2004;18(4):329-32.

TABLE 1 - Prevalence according to the type of cleft and statistic relation $\left(\chi^{2}\right)$ among types of cleft.

\begin{tabular}{|c|c|c|c|c|}
\hline Type of cleft & Prevalence & & $\chi^{2}$ & $\mathrm{p}$ \\
\hline CL & $14.0 \%$ & CL & versus $\mathrm{CP}$ & $0.745 \mathrm{~ns}$ \\
\hline CLP & $22.2 \%$ & CLP & versus $\mathrm{CL}$ & $0.199 \mathrm{~ns}$ \\
\hline $\mathrm{CP}$ & $10.0 \%$ & $\mathrm{CP}$ & versus CLP & $0.066 \mathrm{~ns}$ \\
\hline
\end{tabular}

ns: not significant, $\mathrm{p}>0.05$. CL: cleft lip, CLP: cleft lip and palate, CP: cleft palate.

TABLE 2 - Ankylosed deciduous molars in relation to the affected arch.

\begin{tabular}{l|r|r|r|r|r|r}
\hline \hline \multirow{2}{*}{$\begin{array}{l}\text { Deciduous } \\
\text { molar }\end{array}$} & \multicolumn{2}{|c|}{ Arch } \\
\cline { 2 - 7 } & \multicolumn{2}{|c|}{ Maxilla } & \multicolumn{2}{c}{ Mandible } & \multicolumn{2}{c}{ Total } \\
\cline { 2 - 7 } & $\mathrm{n}$ & \multicolumn{1}{c}{$\%$} & $\mathrm{n}$ & \multicolumn{1}{c}{$\%$} & $\mathrm{n}$ & $\%$ \\
\hline $1^{\text {st }}$ molar & 7 & 50.0 & 69 & 68.3 & 76 & 66.0 \\
\hline $2^{\text {nd }}$ molar & 7 & 50.0 & 32 & 31.7 & 39 & 34.0 \\
\hline Total & 14 & 100.0 & 101 & 100.0 & 115 & 100.0 \\
\hline \hline
\end{tabular}

Regarding gender, 144 patients were females and 186 were males. The sample was divided into three groups according to the age range, as follows: 148 individuals aged 5 to 7 years, 160 individuals aged 8 to 10 years and 22 individuals aged 11 to 12 years.

The prevalence found for the total sample was $18 \%$ (60/330); among females the prevalence was $20.9 \%$ and among males it was $16.1 \%$. The most affected age range was 11-12 years, with a prevalence of $31.8 \%$, followed by $8-10$ years $(24.4 \%)$ and $5-7$ years $(9.5 \%)$. A statistically significant difference was observed when the age range 57 years was compared with the age range 11-12 years $(p=0.008)$ and with the age range $8-10$ years $(p=0.0009)$. The data related to the prevalence of tooth ankylosis according to the type of cleft and the most affected arch and teeth are displayed in Tables 1 and 2, respectively.

\section{DISCUSSION}

Deciduous tooth ankylosis is usually related to the development of malocclusions, since it may cause some alterations in the dental arch, such as inclination of the adjacent teeth, extrusion of the antagonist teeth, decrease in arch perimeter, posterior open bite, development of tongue thrust habit, as well as prolonged retention of the deciduous tooth and delay in the eruption of the successor permanent tooth. These aspects may even exacerbate the orthodontic problems inherent to patients with cleft lip and palate; thus, the knowledge on the occurrence of tooth ankylosis, as well as its early diagnosis and proper intervention may reduce its consequences. Also, deciduous tooth ankylosis has a favorable prognosis when followed up by an orthodontist or a pediatric dentist.

The overall prevalence of tooth ankylosis observed in this study in patients with clefts was $18 \%$. The related literature reports values ranging from $1.08 \%$ to $24.8 \%{ }^{6,7,13,18}$. This large variation may be explained by the lack of standardization in the research methodology and among examiners for clinical diagnosis. The mild degree of infraocclusion proposed by Brearley, McKibben ${ }^{4}$ (1973), (localized occlusal aspect approximately $1 \mathrm{~mm}$ under the occlusal plane in relation to the adjacent non-ankylosed teeth), which is employed in a number of studies, often brings about doubts among examiners, and might lead to diagnosis errors. In some instances, this doubt might be clarified by means of evaluation of the interarch relationship, observing the absence of occlusal contact with the antagonist tooth.

In the evaluation of the presence of ankylosis in relation to gender, no statistical difference could be found between genders. This is in agreement with the findings of Coutinho, Souza ${ }^{6}$ (1994) and Koyoumdjisky-Kaye, Steigman ${ }^{12}$ (1982), even though some authors have observed a larger occurrence among females ${ }^{1,5,14}$ or males ${ }^{10}$.

The higher prevalence of ankylosis at the age ranges $11-12$ (31.8\%) and 8-10 (24.4\%) observed in this study may reflect a tendency, previously reported in the related literature, of an increase in the number of cases upon aging ${ }^{6,12,18}$, or even the progressive nature of ankylosis, which aggravates the degree of infraocclusion, thus providing a better visualization of this anomaly in older patients ${ }^{11-13}$.

No statistical difference between the occurrence of ankylosis and the different types of clefts (Table 1) could be found, suggesting that, even though clefts may bring about distinct dental alterations in the maxilla, according to the diversity of its anatomical involvement, they do not significantly interfere with the occurrence of infraocclusion.

Regarding the tooth and dental arch involved, it was observed that the lower first molar was the most affected tooth, and the mandible was the most affected arch (Table 2), which is in agreement with the majority of studies in noncleft individuals ${ }^{6,7,10,12,18}$. The upper first and second 
Aranha AMF, Duque C, Silva JYB, Carrara CFC, Costa B, Gomide MR. Tooth ankylosis in deciduous teeth of children with cleft lip and/or palate. Braz Oral Res 2004;18(4):329-32.

molars presented a high prevalence of ankylosis (50\%); however, such outcome may be related to the lower number of cases when compared to the mandible.

The similarity among the results of this study and those observed in the literature on noncleft patients points towards the indication of the same type of treatment proposed for tooth ankylosis among the latter, depending on the inherent characteristics of the patient $t^{1,5,8,10}$, of the tooth itself ${ }^{8}$ and of its successor permanent tooth ${ }^{16}$. In addition, prosthetic and surgical procedures ${ }^{1}$ may be required.

Therefore, the findings of this study agreed with those in the literature on noncleft individuals,

\section{REFERENCES}

1. Almeida RR, Martins DR, Ursi WJS, Garms Y. Anquilose de dentes decíduos. Rev Fac Odontol Lins 1990;3:6-12.

2. Andersson L, Blomlöf L, Lindskog S, Feiglin B, Hammarström L. Tooth ankylosis. Clinical, radiographic and histological assessments. Int J Oral Surg 1984;13:423-31.

3. Biederman W. Etiology and treatment of tooth ankylosis. Am J Orthod 1962;48:670-84.

4. Brearley LJ, McKibben DH Jr. Ankylosis of primary molar teeth. I. Prevalence and characteristics. ASDC J Dent Child 1973;40:54-63.

5. Corrêa MSNP, Santos NP, Haddad AE, Kramer PF. Diagnóstico e tratamento da anquilose dento-alveolar em molares decíduos: relato de caso. Rev Fac Odontol FZL 1991;3:10712 .

6. Coutinho TCL, Souza IPR. Contribuição ao estudo da anquilose de molares decíduos em crianças e sua relação com os dentes permanentes sucessores. Rev Bras Odontol 1994;51:18-23.

7. de-la-Rosa-Gay C, Valmaseda-Castellón E, Costa-Codina $\mathrm{X}$, Gay-Escoda C. Infraocclusion of primary molars: reports of cases. ASDC J Dent Child 1998;65:47-51.

8. Dias FL, Moliterno LFM, Oliveira BH. Anquilose dental em molares decíduos. Rev Assoc Paul Cir Dent 1994;48:140913

9. Douglass J, Tinanoff N. The etiology, prevalence, and sequelae of infraocclusion of primary molars. ASDC J Dent Child 1991;58:481-3.

10. Frauches MB, Freitas MPC, Lucca MQ, Marigo M, Pimentel MCMM. Anquilose de molares decíduos: epide- suggesting the absence of influence of the cleft on the presence of tooth ankylosis.

\section{CONCLUSIONS}

In this group of children with cleft lip and/or palate, the following could be observed as to the prevalence of tooth ankylosis:

- the total prevalence was $18 \%$;

- prevalence was not influenced by gender or type of cleft;

- prevalence increased with the increase in age;

- the mandible was the most affected arch, and the lower first molar was the most affected tooth.

miologia e discussão das formas de tratamento. Rev Cient CENBIOS 1993;1:24-35.

11. Gugisch RC, Issao M. Prevalência de anquilose dentoalveolar de molares decíduos em escolares da cidade de Curitiba - PR. Rev Bras Odontol 1994;51:2-9.

12. Koyoumdjisky-Kaye E, Steigman S. Submerging primary molars in Israeli rural children. Community Dent Oral Epidemiol 1982;10:204-8.

13. Kurol J. Infraocclusion of primary molars: an epidemiologic and familial study. Community Dent Oral Epidemiol 1981;9:94-102.

14. Kurol J, Thilander B. Infraocclusion of primary molars with aplasia of the permanent sucessor. A longitudinal study. Angle Orthod 1984;54:283-94.

15. McDonald RE, Avery DR. Erupção dentária: fatores locais, sistêmicos e congênitos que influenciam o processo. In: McDonald RE, Avery DR. Odontopediatria. $4^{\mathrm{a}}$ ed. Rio de Janeiro: Guanabara Koogan; 1986. p. 87-110.

16. Mundstock KS, Prietsch JR. Anquilose de molares decíduos. Rev Odonto Ciênc 1994;9:101-13.

17. Silva Filho OG, Normando ADC, Valladares Netto J. Infra-oclusão de molares decíduos: apresentação de uma conduta racional. Rev Bras Odontol 1992;49:2-7.

18. Vale MPP, Ando T, do Vale CBX, Parreira MLJ. Estudo da prevalência da infra-oclusão de molares decíduos em crianças de Belo Horizonte - MG. RPG Rev Pós Grad 1999;6:50-4. 